\title{
Transitional Cell Neoplasm
}

National Cancer Institute

\section{Source}

National Cancer Institute. Transitional Cell Neoplasm. NCI Thesaurus. Code C6783.

A benign or malignant, primary or metastatic neoplasm affecting the transitional cells. 